\title{
ANALYSIS OF THE LINK BETWEEN CORPORATE GOVERNANCE AND THE PANDEMIC INVESTMENT DECISION
}

https://doi.org/10.47743/jopafl-2021-22-19

\author{
Adelina-Andreea SIRITEANU \\ Doctoral School of Economics and Business Administration,”Alexandru Ioan Cuza” \\ University of Iași, \\ Iasi, Romania \\ siriteanuadelinaandreea@gmail.com
}

Mihaela ONOFREI

Department of Finance, Doctoral School of Economics and Business Administration, "Alexandru Ioan Cuza" University of Iași

Iași, România

onofrei@uaic.ro

\begin{abstract}
In this paper we want to make a presentation of the investments made by companies affected by the coronavirus pandemic and the way in which corporate governance has managed this decision. The crisis caused by the Coronavirus pandemic has affected the HoReCa industry the most in the world (HoReCa is a sector of the hotel and food industry "especially food and beverage establishments"). The crisis caused by Covid-19 has put and continues to put pressure on the Boards of Directors. In large companies, the management of a company is the one that will support the pandemic management on a daily basis. Thus, the Board of Directors has a crucial role, given that it is the body with the ultimate legal responsibility for the organization. It must monitor the actions of managers, assess whether the most appropriate measures are taken. According to economic theory, the demand for investment in pandemics is likely to decrease, as the lack of labor in the economy suppresses the need for large investments. Thus, in order to highlight the effects produced by the pandemic on the investment decision of corporate governance, I will use the competitiveness indicator. In this way I will be able to calculate corporate governance through the responsibility of corporate governance, and competitiveness in the field of analysis meant saving from bankruptcy, surviving the business. In the light of this paper, I would like to highlight the relationship between pandemic and competitiveness-investment. Thus, I will demonstrate how close the connection is between the Boards of Directors and the investment decision during the pandemic.
\end{abstract}

Keywords: corporate governance, investment, pandemic, competitiveness, enterprises

\section{Introduction}

It can be see that until the appearance of this new Covid-19 virus with its possible cataclysmic effects (Washington Post, 2020), and implicitly to "install" the pandemic, the economic context was marked by the globalization, by the finding growing interdependencies between environment and development. Thus, the idea that the responsibility of corporate governance and the approach to sustainable development, which should be an integral part of economic concepts, has begun to take shape. And by creating and maintaining a close link between the two concepts, it is ensured to maintain a balance between economic and social progress and the reserves of natural resources. In the field of tourism, investors and creditors, according to the general framework of the Council for 
International Accounting Standards, should be able to influence management and sustainable development, through partnerships, agreements and by strengthening and using local structures. And investors use company-specific information to make the most appropriate decisions about buying, selling or holding capital.

The aim of the research is to observe the impact of the pandemic on the investment decision of the corporate governance of HoReCa companies.

The objectives we have in this research are:

- determining the correlation between corporate governance and investment decision;

- measuring competitiveness;

- identifying the impact of the pandemic on the financial situation of the analyzed companies.

Operationalization of research by formulating the questions to be answered:

- What is the connection, the correlation between corporate governance and the investment decision?

- What is the link indicator between the 2 terms?

- What is the impact of the pandemic on the companies analyzed?

Hypotheses:

- Corporate governance helps increase competitiveness;

- Increasing competitiveness meant saving from bankruptcy;

- Decreasing investment in the pandemic increases economic performance.

\section{Review of scientific literature}

In the context of the 2020 pandemic, the HoReCa industry was severely affected by the restrictions on movement and social distance imposed by the authorities. Thus, among the multitude of risks faced by these companies in this industry, the pandemic was a new risk, unknown and unquantifiable. The main reason why the HoReCa industry has suffered the most losses is represented by the sanitary rules imposed by governments in order to limit the spread of the virus ( $K \&$ \& , 2020: 2). Thus, in 2020, against the background of the effects of the pandemic, the number of overnight stays registered in the tourist reception structures in the EU countries stood at EUR 1.1 billion in the first 8 months of 2020; a decline of 50\% compared to the same period in 2019. The most severe decrease in the number of overnight stays registered in the EU tourist reception structures in 2020 was in April (95\%) and May (89\%). \%), compared to the same months in 2019.

In the figure 1 we made a presentation of the evolution of the net occupancy rate of beds and bedrooms in hotels in 2019 vs. year 2020. 
Figure 1 The evolution of the net occupancy rate of hotel beds and bedrooms in 2019 vs. 2020

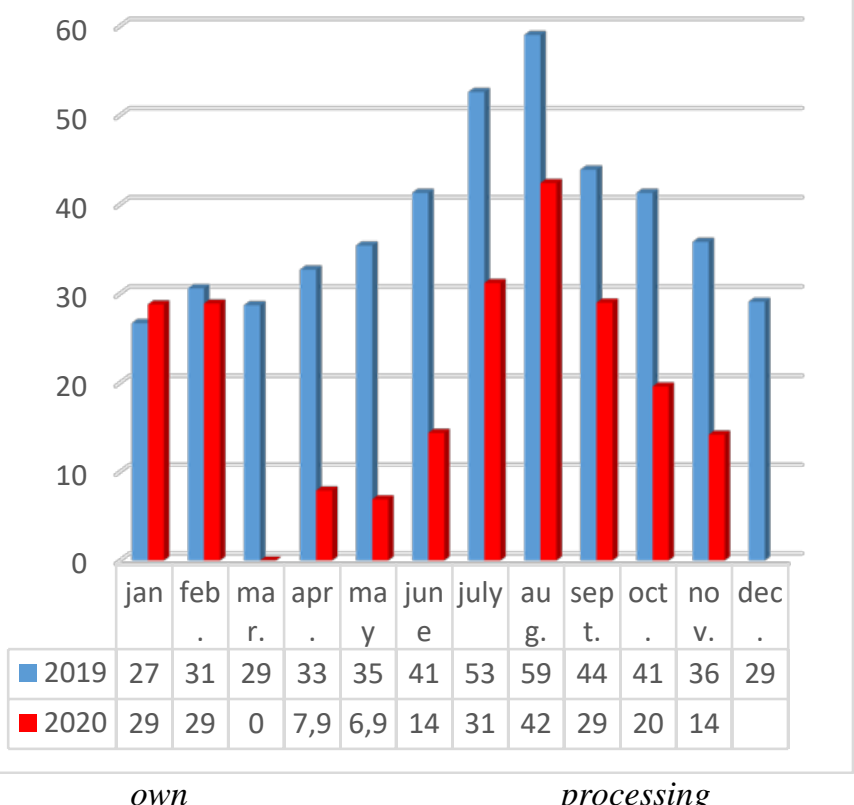

Source:

own

processing

after https://ec.europa.eu/eurostat/databrowser/view/TOUR_OCC_MNOR_custom_552274/default/table?lang $=e n$

The indicator of the net occupancy rate of hotel beds and bedrooms reflects the impact of the pandemic on the hotel industry ( $\mathrm{N}$ et al., 2020: 7). Thus, the lowest value of the indicator is registered in May 2020, respectively 5.9\%. It is not available for March 2020, and no data are available for December 2020. From June 2020 there is an upward trend of this indicator, a trend that is molded for 2019, but not much lower values. And since September 2020 there is a downward trend. A key activity for the Board is determined by the financial impact of the pandemic and the cash flow, as these will determine whether or not the company will survive. Thus, the Board and management must regularly review the company's financial situation, make revenue or cash projections, and explore alternative financing arrangements on an ongoing basis. Health and safety are at the heart of any business that is or is not directly affected by the pandemic. The Board must ensure that the well-being of employees is protected and that responsible action is taken to limit the spread of the virus.

Inland countries, the Covid-19 virus has affected the entire value chain of hospitality, given that events and accommodations have been canceled and restaurants closed. In the case of restaurants, one solution was home delivery, but this was for those who were able to adapt their infrastructure. Tourism has suffered enormously in a few months of pandemic so that we could frequently see the photos posted online with "before" and during the pandemic, with empty stations.

Although the tourism sector has also been affected by crises, as can be seen in figure 2 , none of these events has led to a long-term decline in the global development of tourism. 
Figure 2: The impact of major crisis events on global tourism

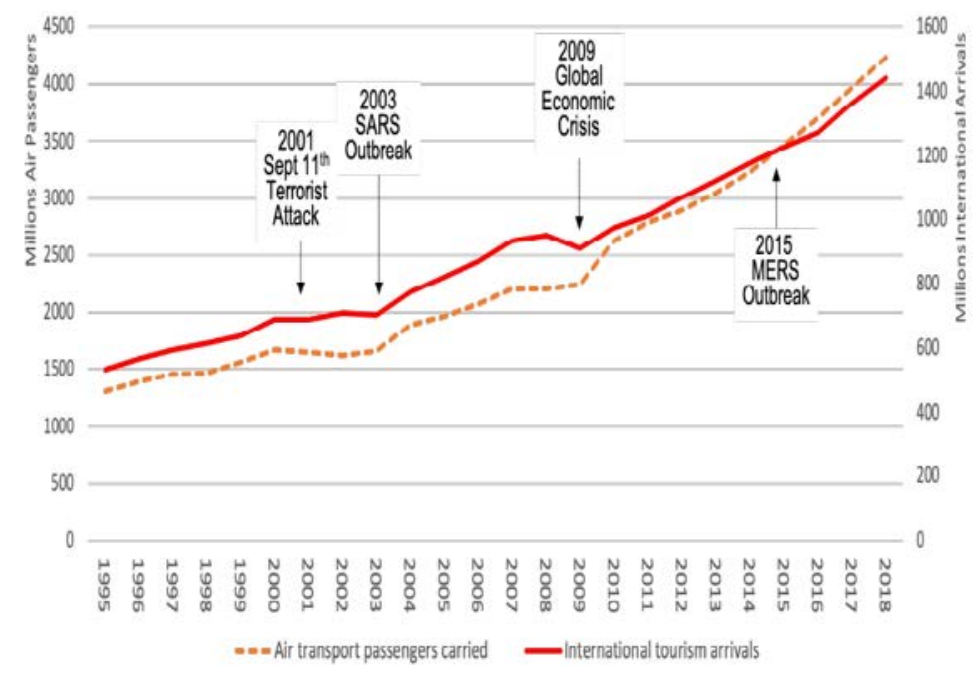

Source:

https://data.worldbank.org/indicator/is.air.psgr

and https://data.worldbank.org/indicator/ST.INT.ARVL

In the period 2000-2015, there were major events that disrupted tourism, and here we can include, the terrorist attacks of 09.11.2001, the outbreak of severe acute respiratory syndrome (SARS) in 2003, the global economic crisis in 2008-2009, as well as and the Middle East Respiratory Syndrome (MERS) of 2015. None of these borderline situations led to the decline caused by the 2020 pandemic; although the events of 2000-2015 also affected tourism, but the share is much lower (for example SARS caused a decrease of $0.4 \%$ and the global economic crisis a loss of $4.0 \%$ of international arrivals). We can see that tourism has been resistant to these shocks, but the losses caused by the pandemic are unprecedented, because tourism revenues are permanently lost; unsold accommodation capacity cannot be traded in the following years. Thus, state governments are beginning to raise awareness of this issue and with the help of the EU provide subsidies to operators operating in this sector. However, there have been voices (G, 2002: 297; P \& Y, 2007: 321; W, 2012: 47-51; S \& G, 2015:275) that have warned of the possibility of a pandemic, as there is a growing mobile population, a global network of transport that facilitates the spread of pathogens ( $\mathrm{P}$ et al., 2009: 8; L et al., 2011: 265-270).

Another perspective adopted in the pandemic comes against the background of changes in consumer behavior and travel demand. A person's behavior is influenced by several factors, among which we can include personal economic well-being, disposable income, changes in accommodation costs, travel, etc. the media in providing information; given that individuals may overreact to various news items. As we have seen, the pandemic has raised new vulnerability issues. And this was also observed among the staff in this sector. Employees in this sector were in low-paid jobs, and the crisis has disproportionately affected them. Thus, tensions arose at the population level, which also generated depression. And a depressed people can no longer find the resources to overcome the problems caused by the pandemic (job loss, technical unemployment, increased likelihood of losing their job, increased risk of illness and death, increased risk of he could not pay his current bills or credit and even the risk of not procuring the necessary food daily). 
Individual problems have also translated into global problems through geopolitical tensions between superpowers and nuclear states, population protests and food security (because farmers can no longer travel to harvest crops; prices for rice, corn and wheat are rising, https://www.nature.com/articles/d41586-020-01999-x).

In the current context of pandemic, globalization, sustainable development and competitiveness, companies are evaluated not only on the basis of economic performance, but also the quality of management policies, which have a significant contribution to the social life of the community of which they are an integral part.

Corporate governance requires a strong management system for any business, and this leads to the consolidation of current and future investors. But the first reference to governance, in modern practice, has its roots in the seventeenth-century Dutch Republic. Thus, the first dispute between shareholders and investors that was registered took place in 1609 within the Dutch East India Company. This company was also the first officially listed in the world. All entrepreneurs want the highest possible market value of their company, and this is achieved through investments. And the market value is nothing but a reasonable estimate, in the current market conditions, of the value of the investment (https://corporatefinanceinstitute.com/resources/knowledge/finance/market-value-vs-

investment-value/). Corporate governance is a system of rules, practices and processes through which a company is controlled and managed. Contemporary references to governance are made through the principles of the Cadbury Report (UK, 1992), the Principles of Corporate Governance (OECD, 1999, 2004 and 2015) and the SarbanesOxley Act (USA, 2002).

In 2008, a paper (B \& B, 2008: 270) was conducted that highlighted the link between the GIM governance index and operational performance (ROA). The study found a $1 \%$ improvement in governance, as measured by the $\mathrm{G}$ index; improvement that is associated with a change of $0.854 \%$ of operational performance in the current period, with a change of $0.763 \%$ in the operational performance of next year and a change of $0.287 \%$ in the next two years of operational performance. There was also a $1 \%$ improvement in governance, as measured by the composite index; this is associated with a change of $1.874 \%$ in operational performance in the current period, a change of $1.567 \%$ next year.

Studies (N \& W, 2008: 205-208) examined the causal relationship between corporate social responsibility (CSR) and financial performance. According to previous studies, it was found that the 2 variables seem to be related when using traditional statistical techniques. However, using a fixed time series approach, the relationship between CSR and financial performance was found to be much weaker than previously thought. Also in this study, little evidence was found of the causality between financial performance and more limited measures of social performance that focus on stakeholder management. The results suggested that the strong performance of the stock market leads to a greater investment in aspects of CSR dedicated to employee relations, but that CSR activities do not affect financial performance. It concludes that CSR is driven more by unobservable characteristics of companies than by financial performance.

Another paper (S et al., 2010:476-481) examined the effects of a company's intangible resources in mediating the relationship between corporate responsibility and financial performance. We hypothesized that past empirical findings of a positive relationship between social and financial performance may be false, because researchers have failed to account for the mediating effect of intangible resources. The result of this 
study indicated that there is no direct relationship between corporate responsibility and financial performance, but there is only an indirect relationship that relies on the mediating effect of a company's intangible resources. The argumentation of the theoretical arguments was made through a database consisting of 599 companies from 28 states. In 2014, another research paper ( $G$ et al., 2014: 249-250) analyzed a sample of companies included in the S\&P 100 index and excluding companies belonging to the financial sector, for 2013. With the help of the sample, the lack of a relationship was highlighted. statistically significant between the global corporate governance rating ISS Governance QuickScore 20, provided by Institutional Shareholder Services INC, and the value of the company, expressed by the Qal Tobin report and the value of the company (both adjusted by industry). The regression model demonstrated the absence of a statistically significant relationship between the ISS and the S\&P 100 companies. It also did not identify any statistically significant relationship between the four ratings provided by the ISS and the Q Tobin report.

In 2015, an empirical research was conducted (G, 2015: 45) on 66 companies listed on BVB, for 2012. In this empirical research, the Q rate (adjusted according to the sector of activity) was used to quantify the value of companies. And in order to assess corporate social responsibility were analyzed: health, safety, security, employee rights, social involvement, environmental protection, quality assurance, safety and effectiveness of products and services. Thus, elaborating the global index and the 4 sub-indices of social responsibility, the control variables were achieved, for which a positive influence correlated with the value of the enterprise was established. There was also a lack of a statistically significant link between the sub-index of corporate social responsibility on environmental protection, weighted equal and the value of the company, between subindices on social involvement of companies, health, security, rights and employee development, environmental protection, adjusted according to stakeholders and the value of the enterprise. Also within this research, a research was conducted on the influence of ISS Governance QuickScore ratings on the value of enterprises listed on BVB. Thus, the research result showed the lack of a statistically significant link between the global corporate governance index reported by Insitutional Shareholder Services and the value of the enterprise, as well as the lack of statistically significant links between the Board structure index, remuneration, shareholder rights reported by ISS and enterprise value.

\section{Research design and methodology}

Following this research of the literature, we found that there is a positive relationship between corporate governance and economic performance. Thus, I will choose to make a comparative study of companies in the HoReCa industry; industry severely affected by the pandemic. But I will note that there is a positive relationship between corporate governance and economic performance. Thus, this positive effect of increasing economic performance is determined by corporate governance through careful management to create and maintain value over the long term ( $T \&$ \& , 2019: 55). And to calculate corporate governance through the responsibility of corporate governance I will choose the COMPETITIVENESS indicator, which in the field of analysis meant saving from bankruptcy, business survival. Competitiveness is a stimulus to markets; stimulus that boosts the entrepreneurial spirit and that makes possible the rapid change to the changes that appear in the application. In the light of this paper, I would like to highlight the 
pandemic-competitiveness-investment relationship; because as some experts ( $T$ \& $G$, 2019: 52) say, efficiency, especially in times of economic crisis, such as the crisis generated by Covid-19, pushes companies to adopt organizational models that reason in terms of periods focusing on saving and reducing costs. Thus, a company, through corporate governance, decides to make investments, through which it attracts more customers and increases its economic and, automatically, divine performance more competitive in the market, even during crises.

In this paper we want to make a comparative analysis of corporate governance of 3 companies in the field of HoReCa, listed on the Bucharest Stock Exchange (Tourism, Hotels, Restaurants Black Sea Corporation, SIF Hotels Corporation and Turism Felix Corporation) in the investment decision, within 2020, a pandemic year. Thus, the procurement of the necessary data in the comparative analysis will be represented by the BVB website, as well as the websites of the aforementioned companies, the annual reports and financial statements.

In order to perform the comparative analysis, I will note the analyzed companies as follows: Tourism, Hotels, Restaurants Black Sea Corporation marked with A, SIF Hotels Corporation marked with B and Felix Tourism Corporation marked with C.

In tables no. 1-6 we made a presentation of competitiveness, which in the field of analysis meant saving from bankruptcy, business survival, measured through 6 indicators, respectively: economic profitability (where, ROA $=$ Net profit / Total assets $* 100$ ), financial profitability (where, ROE = Net profit / Equity), profitability (where, Profitability $=$ Operating profit $/$ Capital employed $* 100$ ), value added (where, Va $=$ Trade margin + Production for the year - Intermediate consumption), market share (where, market share = the total sales volume of the company / the total sales of the 3 companies * 100) and share of turnover in GDP.

\begin{tabular}{|c|c|c|c|c|c|c|c|c|c|c|c|c|c|c|c|}
\hline & & \multicolumn{3}{|c|}{ Tabel no. l: ROA } & & & & & & \multicolumn{3}{|c|}{ Iabel no, 4: Value added } & & & \\
\hline *\% & year 2014 & year 2015 & year 2016 & year 2017 & year 2018 & year 2019 & year 2020 & Wei & year 2014 & year 2015 & year 2016 & year 2017 & year 2018 & year 2019 & year 2020 \\
\hline Company $A$ & 2,51 & 1,71 & 1,72 & 06 & 3,72 & 2,04 & 1,76 & oinpariny 1 & 24.125 .661 & 28.692827 & 29.353930 & 30.348 .552 & 41.690 .626 & 42.211 .598 & 19.109 .292 \\
\hline imparin $B$ & 0,24 & $-8,0$ & & & & & & Iparin 3 & 9.825 .037 & 9.474 .415 & 15.951 .608 & 16.517 .108 & 18.10 .312 & 21.121 .869 & 10.002 \\
\hline \multirow[t]{3}{*}{ Company C } & 2,09 & 2,91 & 3,75 & 2,65 & 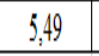 & 5,87 & 0,21 & $p a n y c$ & 35921.496 & 44.870 .214 & 30.945 .541 & 49.919 .036 & 67.005. & 78.497 .568 & 44.6222 \\
\hline & & \multicolumn{3}{|c|}{ Source: own processing } & & & & & & \multicolumn{3}{|c|}{ Soliccé ovin processing } & & & \\
\hline & & \multicolumn{3}{|c|}{ Tabel no. 2: ROE } & & & & & & \multicolumn{3}{|c|}{ 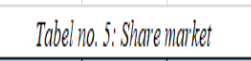 } & & & \\
\hline$\%$ & year 2014 & year 2015 & year 2016 & year 2017 & year 2018 & year 2019 & year 2020 & 406 & year 2014 & year 2015 & year 2016 & year 2017 & year 2018 & year 2019 & year 2020 \\
\hline Company $A$ & 3,32 & 2.25 & 2,13 & 0,88 & 4,28 & 2.29 & 1,94 & Inparing $\mathrm{A}$ & 45,98 & 42,92 & 1031 & 34,71 & 42,80 & 32,77 & 39,88 \\
\hline Company B & 0,24 & $-8,67$ & 3,18 & $-1,61$ & $-1,25$ & 1,55 & $-16,22$ & onporiny B & 14,83 & 12,09 & 16,99 & 20,45 & 15,88 & 15,77 & 10,19 \\
\hline \multirow[t]{3}{*}{ Comparin C } & 2,49 & 3,09 & 3,97 & 2,79 & 5,83 & 6,43 & 0,24 & ippany C & 39,19 & 44,99 & 42,70 & 44,84 & 41,32 & $\$ 1,46$ & 49,93 \\
\hline & & \multicolumn{3}{|c|}{ Solirce: own processing } & & & & & & \multicolumn{3}{|c|}{ Solicere ovin processsing } & & & \\
\hline & & \multicolumn{3}{|c|}{ Iabel no. 3: Profftability } & & & & \multicolumn{7}{|c|}{ Tabel no, 6 : The turnover of fhe compomines in the national GDP } & \\
\hline *\% & year 2014 & year 2015 & year 2016 & year 2017 & year 2018 & year 2019 & year 2020 & $* \%$ & year 2014 & yert 2015 & year 2016 & yera 2017 & year 2018 & year 2019 & year 2020 \\
\hline Compary $\mathrm{A}$ & 3,64 & 2,37 & 2,29 & 1,06 & 5,56 & 3,02 & 2,69 & Conponiny 1 & 0,004414 & 0,04802 & 0,004576 & 0,004012 & 0,004877 & 0,004912 & 0,002426 \\
\hline mpariy $B$ & $-1,11$ & 8,94 & 3,35 & $-0,20$ & $-0,88$ & 0,57 & $-14,71$ & mparin 3 & 0,001718 & 0,001616 & 0,01569 & 0,02415 & 0,002403 & 0,002882 & 0,000875 \\
\hline mpany C & 2,83 & 3,68 & 4,70 & 299 & 6,07 & 8,50 & 3,50 & inparing $C$ & 0,07765 & 0,007772 & 0,008122 & 0,007009 & 0,008342 & 0,00399 & $\overline{0056}$ \\
\hline & & \multicolumn{3}{|c|}{ Solirce: own processing } & & & & & & \multicolumn{3}{|c|}{ Solvere ovin procesessing } & & & \\
\hline
\end{tabular}




\section{Results and discussions}

ROA:

We can see that in the case of company A in the first 2 years analyzed, the ROA indicator registers decreases, but since 2016 the trend registered by this indicator is an ascending one. In the case of company $\mathrm{B}$ we notice a marked evolution of increases and decreases, therefore the management of this company encounters problems in asset management. And company $C$ has an increasing trend in the period 2014-2016 of this indicator. In 2016, there is a decrease of $1.10 \%$ compared to the previous year, and in 2018 it registers the highest value of this indicator in the analyzed period. This increase of the indicator from 2018 can be attributed to the highest level of profit, respectively 12,444,687 lei, but also to assets, respectively 226,688,119 lei. A reason for the increase of assets is given by the increase of the construction and real estate investment group from 4,278,009 lei in 2017 to 17,397,530 lei in 2018. We find that the ROA indicator of the first company, respectively company $\mathrm{A}$, does not fall in the optimal range of developed countries of 3$9 \%$, until 2018. And the other 2 companies analyzed also record lower values than this optimal range; the only exception can be seen in 2016, when company B registers a value of 3.18\% of this indicator. In 2016, 2018 and 2019, company C registers values that fall within the optimal range, so compared to its assets, company $\mathrm{C}$ has a very efficient management.

Company A registers, in 2015, an increase of fixed assets of 9.75\% as a result of the increase of fixed assets by $14.61 \%$ compared to 2014; the increase is based on investments in fixed assets and intangible assets through the purchase of hotel management licenses. In 2016 there is an increase of $1.58 \%$ due to the increase of current assets compared to the level achieved in the previous year; the increase is due to the assets held for sale classified in the category of stocks from 4,073,434 lei in 2015 to 11,007,555 lei in 2016. In 2017 there is a decrease in assets of $2.83 \%$ due to the reduction of the Real estate investment indicator, as a result of the reclassification of the Claudia Complex asset (hotel and restaurant-building and land) from leased assets into assets held for sale. And in 2018 there is an increase of 4.42\%; increase due to the higher level of current assets, by $46.29 \%$ this year compared to 2017, as a result of the increase in cash from 4,439,143 lei on 31.12 .2017 to $27,411,276$ lei on 31.12 .2018 , a percentage increase by $517.49 \%$. In 2020 , fixed assets decreased by 13,674,518 lei compared to 2019.

In 2015, in the case of company B, there is an increase of $25.34 \%$ of total assets, as at the end of October 2015 the merger operation was completed by which this company absorbed 5 other companies (Beta Transport Corporation of Cluj Napoca, Transeuro Hotel Baia Mare, Hotel Meseul Zalău, Rusca Corporation of Hunedoara and Valy Tim Corporation of Timișoara) becoming the majority shareholder. In 2016, there was an increase of $4.15 \%$ in total assets, although the entire patrimony of the Hotel Meses S.A. office was sold; current assets increased due to this fact, holding a share of only $11.97 \%$ of total assets. And in 2017 the effect of this sale is really felt when the value of the assets is negatively influenced by the sale of the Hotel Meses S.A. office, increasing by only $1.73 \%$ during this period. In 2018, current assets decreased by $1.47 \%$ compared to 2017; assets decreased due to an intragroup loan of 3.8 million.

Company $\mathrm{C}$ registers in 2015 a decrease of fixed assets of $7.64 \%$ as a result of the reduction of the cash level from 11,136,546 lei to 10,965,359 lei, as well as the decrease 
of the value of trade receivables by 1,831,074 lei (from 3,553. 384 lei to 1,722,310 lei) in 2015 compared to 2014. In 2016 there is an increase of $1.25 \%$ due to the increase of inventories by $25.38 \%$, but also of cash by 25.84\% in 2015 compared to 2015. In 2017 there is a decrease in assets of $0.14 \%$ due to the decrease of trade receivables by $44.81 \%$ in 2017 compared to 2016. And in 2018 there is an increase of $11.49 \%$; increase due to the higher level of cash (corresponding to the high level of profit this year) by 8,950,143 lei in 2018 compared to the previous year. In 2020, there is a decrease of 18,268,240 lei of fixed assets compared to 2019, as financial assets also decreased by $28.95 \%$ this year compared to 2019.

Within the figure 3 we made a presentation of the evolution of investments in the period 2014-2020.

Figure 3: Evolution of investments in the period 2014-2020, * lei

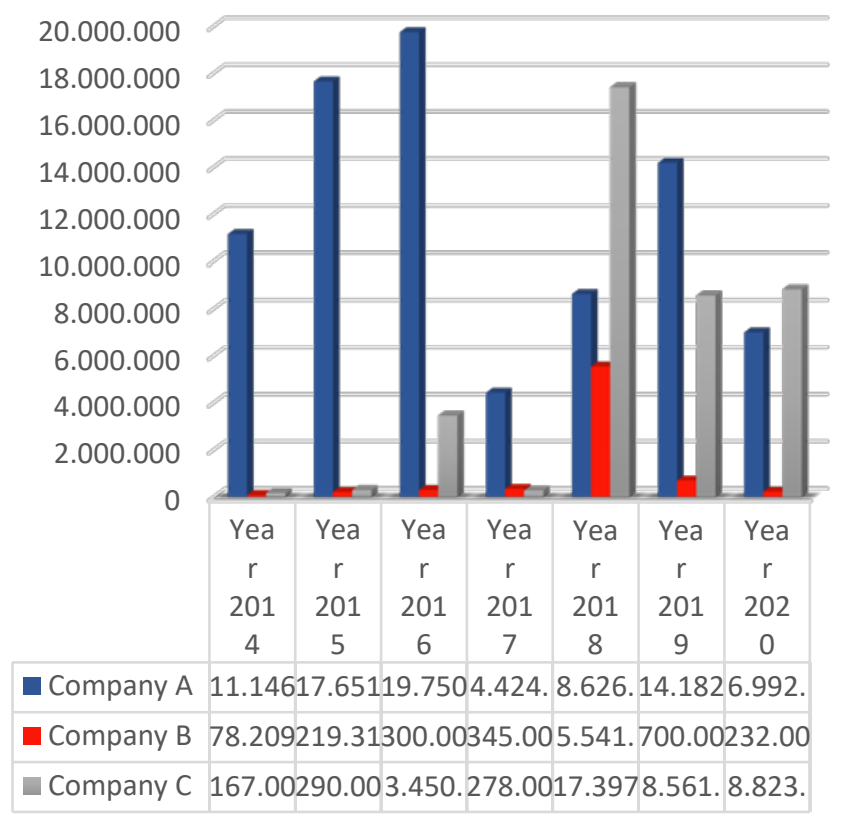

Source: own processing

You can see the increasing trend of investments made by company A in the period 2014-2016, followed by the dramatic decrease in 2017 of 15,326,002 lei compared to the previous year. And in 2018-2019 the increasing trend of investments is observed. In 2017, the lowest level of investments is registered as the Board of Directors decided to allocate money only for the rehabilitation and execution of ventilation and air conditioning installations, ventilation and air conditioning works at heritage hotels and restaurants. Company B registers an upward trend of investments until 2019. In 2014, when the smallest amount allocated for investments is observed and only fixed assets were purchased, among which we can mention hhonors indoor signage, which reduces the level of emissions of heritage cars, and fire alert alert system. Investments made during 2020 mainly involved the purchase of equipment, such as pumps, washing machines, drinking water treatment systems and anti-burglary systems. 
Company $\mathrm{C}$ follows the same upward trend as company $\mathrm{A}$ in the first 3 years analyzed, followed by a decrease in 2017. In 2018 the high level of investment is due to investment in 5 complexes of the company for modernization, maintenance and new design of rooms, restaurants (indoor + outdoor), in 2 swimming pools for beach modernization works and for the purchase and installation of a $4 \mathrm{~kW}$ air compressor, in the administrative headquarters for repartitioning offices and interior finishing works and in drilling and well works for the procurement and installation works of the pumping group in the Balint spring. The pandemic was invested in the 5 complexes owned by the company, in 3 swimming pools and in the administrative headquarters. The investment activity of company $\mathrm{C}$ focused mainly on the modernization of 55 bathrooms and the replacement of bathtubs with shower trays, the purchase of a cosmetic combine, a magnetodiaflux device and a massage bed in the treatment base, installation of a cold room $35 \mathrm{~m} 3$, modernization works were carried out on the interior finishes in the restaurants' kitchen, an IMP recirculation pump and a Wilo recirculation air conditioning pump were purchased and landscaping works were carried out on the access road to Hotel Poienița and Hotel Mureș.

ROE:

We find that the ROE indicator of the first company, respectively company A, registers in 2018 the highest level, respectively 4.28\%. This year, company A also had the highest level of profit, respectively 9,823,215 lei, but also of its own capital, respectively 240,857,925 lei. Company B records negative values of this indicator in 2015, when the result for the year is negative, respectively -9,593,167 lei (when the level of trade debts increased greatly from 825,063 lei in 2014 to 1,193,181 lei in 2015), in 2017, when we have a loss of 1,894,678 lei, and in 2018, when the loss was worth 1,443,536 lei (the value of expenses increased quite a lot, exceeding revenues, because the securities held had a negative evolution.). Company $\mathrm{C}$ registers in 2018 the highest value of this indicator, when the highest value of profit is registered, 12,444,687 lei, and of own capital, 213,625,096 lei.

\section{Profitability:}

We notice that in the first 3 years analyzed from 2014-2017, company A has a decreasing profitability, therefore there is an increase in costs. And from 2018 there is a new decreasing trend. Company $\mathrm{C}$ has an increasing profitability in the first 3 analyzed, unlike company A. And company B has a profitability with a decreasing trend in the period 2015-2018. It is observed that in 2020 all companies have a decreasing profitability compared to 2019.

\section{Added value:}

It can be seen that company A has an upward trend in the value added indicator. Therefore, it has a growing economic power. Company B also has an upward evolution in the period 2015-2019. In the case of company C, it is observed that it has a higher added value than the other 2 companies analyzed for the entire period between 2014-2020, and the evolution is mainly ascending. In 2020 there are significant decreases in all companies compared to 2019.

\section{Market share:}


We considered the 3 analyzed companies as the only ones in this sector in order to be able to measure the total revenues of the industry; as we did not find the level of total industry revenue annually. It can be seen that the market share indicator has a predominantly decreasing evolution, in the case of company A. But in 2020 it is observed that the company has an increase in the indicator, unlike the other 2 companies. The main reason is the decrease of revenues by only $27.40 \%$ in 2020 compared to 2019 compared to the other 2 which had a decrease of $61.46 \%$ and $42.12 \%$ in 2020 compared to 2019.

\section{Share of the turnover in GDP}

It can be seen that the highest share in GDP has the turnover of company C throughout the analyzed period. And this company registers a predominantly upward trend of turnover in GDP between 2014-2019. But the 2020 pandemic has led to a severe decline from the previous year. Company A has a downward evolution in the period 2015-2017 and an upward one in the period 2018-2019. And company B has a predominantly downward evolution in 2014-2020.

\section{Conclusions}

At the level of 2020, company C holds the leading position. Thus, at the level of 2020, company $C$ has the highest values for 4 indicators, namely profitability, value added, market share and share of turnover in GDP. In 2020 it is found that the highest value of the profitability is $3.50 \%$ and is registered by company C; however, compared to 2019, there is a decrease of $5.01 \%$ in the profitability of companies C. While company A registers a decrease in profitability of only $0.33 \%$ in 2020 compared to 2019 . The highest added value in 2020 is company C, respectively 44,622,260 lei; and the decrease compared to 2019 is $33,875,308$ lei. And the company registers in the pandemic a loss of added value of only 23,312,306 lei. The market share registered by company C, the highest in 2020, is 49.93\%; and compared to 2019 there is a decrease of $1.53 \%$. And company A registers an increase of the market share, in 2020, of 7.11\% compared to 2019. The share of CA in GDP is the highest in the case of companies C, respectively $0.005653 \%$. Therefore, we can say that although it was affected by the lock-down and the initial restrictions given in the pandemic, in the end, the corporate governance managed to manage the pandemic well. In other words, a stable and strong company can be affected by a pandemic, as it happened in the case of companies, but a strong analyzed company can return faster, and the increase of investments meant the realization of a future strategy. Thus, in the pandemic, at the level of 2020, this company increased investments by 262,087 lei compared to the previous year. So, although in the short run it suffered losses, in the long run this pro-investment position led to the maintenance of the market position.

We can say that company $\mathrm{C}$ tended to increase its market share before the pandemic. Thus, even in the pandemic, he resorted to increasing investments to continue his policy. However, we find that the decision of company A to change its Board of Directors was an inspired decision, as the change had a favorable impact on the financial situation of this company. According to the economic theory in the pandemic, it is possible that the level of investments will decrease. Yes... but a strong company and a management focused on the company can make investments lead to a strong company on the market. 


\section{References}

Specialty articles:

1. Bhagata S., Bolton B., (2008). Corporate governance and firm performance. Journal of Corporate Finance Volume 14, Issue 3 (https://www.sciencedirect.com/science/article/pii/S0929119908000242\#sec2);

2. Gherghina S.C., (2015). Analysis and evaluation of the impact of corporate governance on the value of the enterprise, Bucharest Academy of Economic Studies

3. Gherghina, Ş. C., Vintilă, G., Țibulcă, I. L., (2014). A study on the relationship between corporate governance ratings and company value: Empirical evidence for S\&P 100 companies. International Journal of Economics and 6inance, 242-253 (https://www.researchgate.net/publication/263475975_A_Study_on_the_Relationship_between_Corporate _Governance_Ratings_and_Company_Value_Empirical_Evidence_for_SP_100_Companies)

4. Gössling, S., (2002). Global Environmental Change, Global environmental consequences of tourism, https://doi.org/10.1016/S0959-3780(02)00044-4

5. Hall, C. M., (2006). Tourism and global environmental change: Ecological, economic, social and political interrelationships, Tourism, biodiversity and global environmental change. In S.Gössling \& C. M.Hall (Eds.), Routledge

6. Ka Wai Lai I., Chou Wong J. W., (2020).Comparing crisis management practices in the hotel industry between initial and pandemic stages of COVID-19, International Journal of Contemporary Hospitality Management. Volume 32 Issue 10; https://doi.org/10.1108/IJCHM-04-2020-0325

7. Labonte, R., Mohindra, K., Schrecker, T., (2011). The growing impact of globalization for health and public health practice. Annual Review of Public Health, 263-283 https://doi.org/10.1146/annurevpublhealth-031210-101225

8. Napierała T, Leśniewska-Napierała K, Burski R., (2020). Impact of Geographic Distribution of COVID19 Cases on Hotels' Performances: Case of Polish Cities. Sustainability; https://doi.org/10.3390/su12114697 9. Nelling, E., Webb, E., (2008). Corporate social responsibility and financial performance: The "virtuous circle” revisited. Review of Quantitative Finance and Accounting, 32(2): 197-209; https://doi.org/10.1007/s11156-008-0090-y

10. Onofrei, M., \& Lupu, D. (2014). The modeling of forecasting the bankruptcy risk in Romania. Economic Computation \& Economic Cybernetics Studies \& Research, 48(3). 249-267

11. Page, S., Yeoman, I., (2007). How VisitScotland prepared for a flu pandemic. Journal of Business Continuity \& Emergency Planning, 1 (2), 167-182;

12. Pongsiri, M. J., Roman, J., Ezenwa, V. O., Goldberg, T. L., Koren, H. S., Newbold, S. C., Ostfeld, R. S., Pattanayak, S. K., Salkeld, D. J., (2009). Biodiversity loss affects global disease ecology. BioScience, 945954, https://doi.org/10.1525/bio.2009.59.11.6

13. Scott, D., Gössling, S., (2015). What could the next 40 years hold for global tourism?. Tourism Recreation Research , 40 (3), 269-285. https://doi.org/10.1080/02508281.2015.1075739

14. Surroca, J., Tribó, J. A., Waddock, S., (2010). Corporate responsibility and financial performance: The role of intangible resources, Strategic Management Journal, 31(5): 463-490; https://doi.org/10.1002/smj.820 15. Tommaso, F. D., Gulinelli, A., (2019). Corporate Governance and Economic Performance: The Limit of Short Termism, Financial Markets, Institutions and Risks, 3(4), 49-61.

\section{Legislation:}

15. Decision no. 394 of 18 May 2020 on the declaration of the state of alert and the measures applied during it to prevent and combat the effects of the COVID-19 pandemic;

16. Decision no. 476 of June 16, 2020 on the extension of the state of alert on the territory of Romania and the measures applied during it to prevent and combat the effects of the COVID-19 pandemic;

17 Law no. 55/2020 on some measures to prevent and combat the effects of the COVID-19 pandemic, published in the Official Gazette, Part I no. 396 of May 15, 2020.

Websites:

18.https://ec.europa.eu/eurostat/databrowser/view/TOUR_OCC_MNOR_custom_552274/default/table?la ng=en

19. https://corporatefinanceinstitute.com/resources/knowledge/finance/market-value-vs-investment-value/

20. https://data.worldbank.org/indicator/is.air.psgr 
21. https://data.worldbank.org/indicator/ST.INT.ARVL

22.https://insp.gov.ro/dj/comunicate/Recomandari\%20masuri\%20speficice\%20dupa\%20starea\%20de\%20u rgenta.pdf;

23. https://lege5.ro/Gratuit/gi2tsmbqhe/novatia-codul-civil?dp=gu3dmnjtgi3ts;

24. https://sif-hoteluri.ro/relatia-investitori/aga/\#163-materiale-informative-agoa-2930-04-2021;

25. https://thrmareaneagra.ro/wp-content/uploads/2021/03/Punctul-1-Raport-anual-2020_Situatiifinanciare-individuale.pdf;

26. https://www.cnscbt.ro/index.php/legislatie_cov/1767-legea-nr-55-2020-privind-unele-masuri-pentruprevenirea-si-combaterea-efectelor-pandemiei-de-covid-19/file;

27. https://www.iod.com/news/news/articles/The-corporate-governance-of-coronavirus---what-boardsshould-consider;

28. https://www.nature.com/articles/d41586-020-01999-x;

29. https://www.turismfelix.eu/documente_aga_2021/AGOA_19042021/TUFE_AGA_RapCA2020.pdf;

30. https://www.washingtonpost.com/national-security/us-intelligence-reports-from-january-and-februarywarned-about-a-likely-pandemic/2020/03/20/299d8cda-6ad5-11ea-b5f1-a5a804158597_story.html.

Reports:

31. https://sif-hoteluri.ro/relatia-investitori/situatii-financiare/\#17-2014;

32. https://sif-hoteluri.ro/relatia-investitori/situatii-financiare/\#17-2015;

33. https://sif-hoteluri.ro/relatia-investitori/situatii-financiare/\#17-2016;

34. https://sif-hoteluri.ro/relatia-investitori/situatii-financiare/\#17-2017;

35. https://sif-hoteluri.ro/relatia-investitori/situatii-financiare/\#17-2018;

36. https://sif-hoteluri.ro/relatia-investitori/situatii-financiare/\#17-2019;

37. https://sif-hoteluri.ro/relatia-investitori/situatii-financiare/\#17-2020;

38. https://bvb.ro/infocont/infocont20/EFO_20200423141731_B-Raport-anual-2014-RO.pdf;

39. https://bvb.ro/infocont/infocont20/EFO_20200423141731_B-Raport-anual-2015-RO.pdf;

40. https://bvb.ro/infocont/infocont20/EFO_20200423141731_B-Raport-anual-2016-RO.pdf;

41. https://bvb.ro/infocont/infocont20/EFO_20200423141731_B-Raport-anual-2017-RO.pdf;

42. https://bvb.ro/infocont/infocont20/EFO_20200423141731_B-Raport-anual-2018-RO.pdf;

43. https://bvb.ro/infocont/infocont20/EFO_20200423141731_B-Raport-anual-2019-RO.pdf;

44. https://bvb.ro/infocont/infocont20/EFO_20200423141731_B-Raport-anual-2020-RO.pdf;

45.https://www.turismfelix.eu/documente_aga_2015/RaportAnual2014/TUFE\%20AGOA\%202016.04.08\%

20-\%201.2\%20Raport\%20anual\%20ASF.pdf;

46.https://www.turismfelix.eu/documente_aga_2016/RaportAnual2015/TUFE\%20AGOA\%202016.04.08\%

20-\%201.2\%20Raport\%20anual\%20ASF.pdf;

47.https://www.turismfelix.eu/documente_aga_2017/RaportAnual2016/TUFE\%20AGOA\%202016.04.08\%

20-\%201.2\%20Raport\%20anual\%20ASF.pdf;

48.https://www.turismfelix.eu/documente_aga_2018/RaportAnual2017/TUFE\%20AGOA\%202016.04.08\%

20-\%201.2\%20Raport\%20anual\%20ASF.pdf;

49.https://www.turismfelix.eu/documente_aga_2019/RaportAnual2018/TUFE\%20AGOA\%202016.04.08\%

20-\%201.2\%20Raport\%20anual\%20ASF.pdf;

50.https://www.turismfelix.eu/documente_aga_2020/RaportAnual2019/TUFE\%20AGOA\%202016.04.08\%

20-\%201.2\%20Raport\%20anual\%20ASF.pdf;

51.https://www.turismfelix.eu/documente_aga_2021/RaportAnual2020/TUFE\%20AGOA\%202016.04.08\%

20-\%201.2\%20Raport\%20anual\%20ASF.pdf;

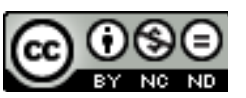

This article is an open access article distributed under the terms and conditions of the Creative Commons Attribution - Non Commercial - No Derivatives 4.0 International License. 